\title{
Influence of a polymorphism ILIB gene in the response of rheumatoid arthritis and ankylosing spondylitis patients treated with infliximab
}

\author{
M J Morales-Lara' ${ }^{1}$, P Conesa-Zamora ${ }^{2 *}$, V Santaclara², D Torres-Moreno², F Pedrero ${ }^{3}$, J Moreno-Morales ${ }^{4}$, V Cogolludo ${ }^{4}$ \\ From 5th European Workshop on Immune-Mediated Inflammatory Diseases \\ Sitges-Barcelona, Spain. 1-3 December 2010
}

\section{Introduction}

Cytokines such as IL1 are central mediators of joint inflammation in patients with rheumatoid arthritis (RA) and ankylosing spondylitis (AS) and polymorphism in IL1 has been associated with disease susceptibility and severity.

\section{Aim}

To evaluate the role of the polymorphism rs1143634 in the IL1B gene in the pharmacogenetic of RA and AS patients treated with infliximab.

\section{Patients and methods}

IL1B genotyping was performed in a subset of $42 \mathrm{RA}$ and 39 AS patients treated with infliximab. Response was assessed at the $3^{\text {rd }}$ and $6^{\text {th }}$ month of treatment by EULAR for RA and BASDAI criteria for AS.

\section{Results}

According to the EULAR criteria no significant associations were found between $I L 1 B$ genotypes and response in RA patients. Distribution of IL1B rs1143634 genotype revealed a significant association in AS between the $\mathrm{T}$ allele with better response (responders: $\mathrm{T}$ 93.5\%, C $60.4 \%$ vs. non responders: T 6.7\%, C 39.6\%; $\mathrm{p}=0.007$ ) and between $\mathrm{TT}+\mathrm{TC}$ genotypes and better response (CC $52.4 \%$ vs. $92.3 \% \mathrm{TT}+\mathrm{TC} ; \mathrm{p}=0.009$ ) at 3 months after treatment commencement according to BASDAI criteria.

\section{Conclusions}

rs1143634 seems to influence the response to infliximab treatment in AS but not in AR patients though this finding must be confirmed in a study with larger sample size.

\section{Author details \\ 'Pharmacy Dept., SM Rosell University Hospital (HUSMR), Cartagena, Spain. ${ }^{2}$ Molecular Pathology and Pharmacogenetics Group FFIS011, HUSMR, \\ Cartagena, Spain. ${ }^{3}$ Day Hospital, HUSMR, Cartagena, Spain. ${ }^{4}$ Rheumatology Dept., HUSMR, Cartagena, Spain.}

Published: 25 November 2010

doi:10.1186/1479-5876-8-S1-P51

Cite this article as: Morales-Lara et al:: Influence of a polymorphism IL1B gene in the response of rheumatoid arthritis and ankylosing spondylitis patients treated with infliximab. Journal of Translational Medicine 2010 8(Suppl 1):P51.
Submit your next manuscript to BioMed Central and take full advantage of:

- Convenient online submission

- Thorough peer review

- No space constraints or color figure charges

- Immediate publication on acceptance

- Inclusion in PubMed, CAS, Scopus and Google Scholar

- Research which is freely available for redistribution
() Biomed Central 